Kiryoku, Volume 3 No 32019

e-ISSN: 2581-0960 p-ISSN: 2599-0497

Tersedia online di http://ejournal.undip.ac.id/index.php/kiryoku

\title{
STUDI TENTANG IDENTITAS JATI DIRI BANGSA JEPANG DALAM KAJIAN FILOSOFIS
}

\author{
Iriyanto Widisuseno \\ Universitas Diponegoro \\ widisusenoiriyanto@yahoo.co.id
}

\begin{abstract}
Abstrak
Penelitian ini mengkaji identitas jati diri bangsa Jepang melalui cara pendekatan filosofis. Pendekatan filosofis ingin menggali nilai-nilai dasar kehidupan yang sedemikian mendasar menjiwai dan memberi watak cara berfikir dan cara pandangnya mengenai arti hidup dan kehidupan bermasyarakat dan berbangsa. Bangsa Jepang dikenal memiliki sosok kemandirian, pekerja keras, ulet dan santun, sehingga selalu dianggap sebagai model negara yang sukses menjalankan modernisasi yang berbasis nilai tradisi budayanya. Peran negara Jepang bagi kemajuan perekonomian Indonesia sangat besar, terutama melalui program investasi jasa dan industri. Hasil penelitian menemukan Bushido sebagai nilai dasar kehidupan yang menjiwai dan memberi watak cara berfikir dalam mengartikan hidup dan kehidupan bangsa Jepang. Bushido dalam manifestasinya sebagai identitas jati diri bangsa Jepang melalui delapan kebajikan Bushido yang mengandung nilai moral: $G i$ (integritas), Yu (keberanian), Jin (Murah Hati), Jin ( Murah Hati), Rei (Hormat dan Santun kepada orang lain), Makoto - Shin (Kejujuran dan tulus ikhlas), Meiyo ( menjaga nama baik dan kehormatan), Chugo (kesetiaan pada pemimpin), Tei( peduli),

Hasil penelitian ini dapat memberi inspirasi bagi pengembangan strategi dan substansi pendidikan karakter di Indonesia.
\end{abstract}

Kata kunci :identitas jati diri; pendekatan filosofis; bangsa Jepang; nilai dasar kehidupan.

\begin{abstract}
This research examines the identity of the Japanese nation through a philosophical approach. Philosophical approach wants to explore the basic values of life that are so fundamental to animating and giving character to the way of thinking and perspective on the meaning of life and life in society and nation. The Japanese nation is known to have a figure of independence, hardworking, resilient and polite, so it is always considered a model of a country that successfully runs modernization based on the values of its cultural traditions. The role of the Japanese state for the progress of the Indonesian economy is very large, especially through services and industry investment programs. The results of the study found Bushido as the basic value of life that animates and gives character to the way of thinking in interpreting the life and life of the Japanese nation. Bushido in its manifestation as the identity of the Japanese nation through eight Bushido virtues which contain moral values: Gi (integrity), Yu (courage), Jin (generous), Jin (generous), Rei (respect and courtesy to others), Makoto - Shin (Honesty and sincerity), Meiyo (maintaining good name and honor), Chugo (loyalty to leaders), Tei (caring), The results of this study can inspire the development of strategies and substance of character education in Indonesia.
\end{abstract}

Keywords: identity, philosophical approach; Japanese nation; basic values of life 


\section{PENDAHULUAN}

Bangsa Jepang dikenal sebagai bangsa yang memiliki sosok kemandirian, pekerja keras, disiplin dan tak kenal menyerah. Seperti yang terjadi ketika Perang Dunia II (1945) kota Nagasaki dan Hirosima Jepanghancur akibat serangan bom Atom oleh tentara Sekutu Amerika. Kemudian juga situasi saat peristiwa gempa bumi dan Tsunami (2011)di wilyah Tohoku Jepang. Ribuan korban jiwa dan fasilitas umum milik negara hancur. Dalam waktu singkat bangsa Jepang dapat berbenah diri dan mengatasi tanpa harus melibatkan bantuan bangsa lain. Sekarang Jepang sudah berkembang sebagai negara maju di segala bidang kehidupannya (Widisuseno, Iriyanto, 2016). Fakta sebagaimana tersebut menunjukkan bahwa bangsa Jepang memiliki kekuatan nilai dasar kehidupan yang sedemikian mendasar dalam menjiwai dan memberi watak cara berfikir dan cara pandangnya mengenai arti hidup dan kehidupan bermasyarakat dan berbangsa.

Nilai-nilai dasar tersebut secara intrinsik berwujud dan bersifat filosofis, sedangkan secara ekstrinsik (praktis) berupa pandangan hidup. Secara intrinsik filosofis nilai-nilai dasar kehidupan mengandung ajaran yang mampu mempengaruhi alam pikiran masyarakat Jepang. Sebagai manifestasinya dalam kehidupan berbangsa dan bernegara, nilainilai dasar itu diyakini sebagai puncak budaya bangsa, jiwa dan kepribadaian bangsa Jepang. Relevansi pendekatan filosofis di sini terletak pada kajian mendalam tentang bagaimana kerangka ontologis, epistemologis dan aksioloigis nilai-nilai dasar kehidupan masyarakat Jepang yang dalam manifestasinya sebagai puncak budaya dan kepribadian bangsa Jepang.

Penelitian tentang nilai-nilai karakter bangsa Jepang telah banyak dilakukan oleh peneliti sebelumnya, mereka mengkaji dari sudut pandang yang berbeda. Takeji Furukawa (1927), meneliti karakter orang Jepang dari segi genetika, yaitu jenis golongan darah. Dalam penelitiannya dinyatakan, golongan darah manusia ditentukan oleh protein-protein tertentu. Protein tersebut membangun semua sel di dalam tubuh manusia, dan oleh karenanya juga menentukan psikologi kita (Weliyati, Anwar, 2015). Peneltian lain dilakukan oleh Rosita Ningrum (2011), tentang Kanyoku Verba "Dekiru" dalam konteks sosiolinguistik. Hasil penelitian ini dapat menunjukkan, dengan belajar Idiom akan memahami akar budaya dalam bahasa yang dipelajari serta bagaimana menyampaikannya sebagai bentuk komunikasi yang tidak sekedar gramatikal saja. Penelitian lainnya dilakukan oleh Iriyanto Widisuseno, Sri Wahyu Utami dan Yuliani Rahmah (2015), tentang Kanyouku sebagai representasi nilai budaya masyarakat Jepang. Melalui penelitiannya dinyatakan, dalam kanyouku terkandung ajaran nasihat, dan nilai-nilai kebijakan hidup. Melalui kanyouku kita dapat mengetahui karakter dan watak masyarakat tempat berkembangnya idiom tersebut.

Penelitian kami ini merupakan sebuah kajian filosofis, untuk menggali kerangka dasar eksistensi kultural bangsa Jepang, mencakup : nilai-nilai dasar kehidupan yang melandasi terbentuknya identitas jati diri bangsa Jepang (kajian ontologis); bagaimana cara mewujudkan nilai dasar kehidupan yang melandasi terbentuknya identitas jati diri bangsa Jepang (kajian epistemologis); norma dasar apa yang dijadikan pegangan dan arah dalam mencapai mengembangkan identitas jati diri bangsa (kajian aksiologis ).Hasil kajian filosofis dari penelitian ini memperoleh pemahaman tentang profil identitas jati diri bangsa Jepang secara mendasar dan holistic, menemukan profil secara utuh.

Urgensi kajian jati diri bangsa sebagai upaya menyikapi berbagai persoalan mendasar tentang jati diri bangsa 
Indonesia, bahwa: (a) Bangsa Indonesia saat ini sedang menghadapi berbagai persoalan internal bangsa, yaitu semakin marak fenomena sosial dan budaya yang menggambarkan situasi kehidupan masyarakat semakin lemah komitmen terhadap nilai -nilai dasar kehidupan yang telah lama dijadikan sebagai pedoman hidup dan pandangan hidup bangsa. Sementara saat ini pada sebagian besar masyarakat lebih memilih dan berpegang pada nilai-nilai modern yang berorientasi pragmatis dan positivistik. Sebaliknya, nilai-nilai dasar (core values) kehidupan yang dulu diyakini sebagai sesuatu yang luhur, sekarang dianggapnya sebagai sesuatu yang sudah ketinggalan jaman (out of date). Faktanya sekarang, timbul berbagai anarkhisme sosial yang mengarah terjadinya krsis jati diri bangsa; (b) Bangsa Indonesia sedang menghadapi tantangan era revolusi industri 4.0 yang serba "digitalized dan disruptive, tentu menuntut kesiapan kualits SDM yang memiliki sikp mental dan jati diri yang kuat dalam menghadapi perubahan yang cepat dan berbagai dampaknya. (c) Kesadaran tanggungjawab moral melihat fenomena dan realitas sosial budaya tersebut terpanggil untuk memikirkan serta mencarikan akar permasalahan serta jalan keluar dari persoalan kebangsaan yang sedang dihadapi bangsa Indonesia (Widisuseno, Iriyanto, dkk, 2018).

\section{METODE DAN SUMBER DATA PENELITIAN}

Penelitian ini termasuk jenis penelitian kualitatif, dan etnografis. Untuk memperoleh data penelitian menggunakan studi literature dari buku-buku referensi yang berkaitan dengan karakter dan filsafat orang Jepang. Objek material penelitian ini adalah identitas jati diri bangsa Jepang, dan objek formal penelitiannya adalah identitas jati diri bangsa Jepang dikaji dari sudut pandang filosofis ( esensial, komprehensif dan normative). Melalui sudut pandang filosofis diperoleh pemahaman kerangka dasar ontologis, epistemologis dan aksiologis tentang identitas jati diri bangsa Jepang. Tujuannya dapat menangkap profil dan kerangka dasar identitas jati diri bangsa Jepang secara utuh.

Tahapan metodoligisnya, diawali pendekatan esensial untuk melihat kerangka dasar ontologis identitas jati diri bangsa Jepang dari kerangka pandangan substantive. Yakni, nilai-nilai dasar apa yang melandasi pemahaman bangsa Jepang tentang hakikat hidup dan kehidupan dalam bermasyarakat dan berbangsa. Kemudian tahap pendekatan komprehensif, untuk melihat kerangka dasar epistemologis identitas jati diri bangsa Jepang dari kerangka pandangan metodis. Yakni bagaimana cara bangsa Jepang mewujudkan konsep hakikat hidup dan kehidupan dalam bermasyarakat dan berbangsa. Diakhiri pendekatan normatif untuk melihat kerangka dasar aksiologis identitas jati diri bangsa Jepang dari kerangka pandangan normatif. Yakni sistem nilai apa yang dipegang dan menjadi arah tujuan hidup. Capaian metodologisnya, yaitu memperoleh profil identitas jati diri bangsa Jepang yang terbentuk dari unsur-unsur kerangka ontologis, epistemologis dan aksiologis eksistensi kehidupan masyarakat bangsa Jepang.

\section{PEMBAHASAN}

\subsection{Pengertian Identitas Jati Diri}

Pengertian identitas jati diri menggambarkan ciri khas siapa diri kita sesungguhnya, di dalamnya mengandung kompleksitas dan ciri tertentu yang menandai diri seseorang atau bangsa, sehingga berbeda dengan diri atau bangsa lain. Identitas jati diri mencerminkan rasa bangga, setia sebagai bangsa. Jika terdapat suatu bangsa yang memiliki keterbatasan wilayah dan sumber daya alam, tetapi masyarakatnya memiliki keteguhan jiwa dan jati diri, akan mampu menjadi bangsa 
yang unggul (Widisuseno, Iriyanto, 2019). Jika terdapat suatu bangsa yang memiliki keterbatasan wilayah dan sumber daya alam, tetapi masyarakatnya memiliki sosok kemandirian sebagai bangsa, keteguhan jiwa dan pantang menyerah, akan mampu menjadi bangsa yang unggul. Sebagai contoh, Jepang telah membuktikan secara nyata. Masyarakat Jepang sangat menyadari akan pentingnya landasan dan pendidikan karakter yang baik bagi warga masyarakat. Artinya, identitas jati diri harus dibangun melalui pembiasaan hal-hal yang baik dari tradisi lingkungan sejak anak usia dini. Sehingga hasil dari pendidikan di Jepang adalah keunggulan jati diri dan karakter yang kuat.

3.2. Kajian Filosofis tentang Identitas Jati Diri Bangsa Jepang

\subsubsection{Kerangka Ontologis}

Nilai dasar kehidupan apa yang sedemikian mendasar menjiwai dan memberi watak cara berfikir dan cara bertindak bangsa Jepang mengenai arti hidup dan kehidupanbermasyarakat,berbangsa dan bernegara.Nilai dasar itu secara instrinsik berwujud dan bersifat filosofis, sedang secara ekstrinsik (praktis) berupa pandangan hidup. Nilai-nilai tersebut merupakan kebulatan ajaran tentang tentang berbagai bidang kehidupan masyarakat bangsa Jepang. Ajaran filsafat itu sedemikian kuat mempengaruhi alam pikiran bangsa Jepang, berupa cara pandangnya mengenai arti hidup dan kehidupan dalam bermasyarakat dan bernegara.

Sebagai manifestasinya dalam kehidupan berbangsa dan bernegara, nilai dasar kehidupan itu diyakini sebagai puncak budaya bangsa, jiwa dan kepribadian bangsa. Sedemikian mendasar nilai-nilai tersebut dalam menjiwai dan memberi watak bangsa, sehingga membentuk identitas jati diri bangsa Jepang (Widisuseno, Iriyanto, dkk, 2007).
Kekuatan keyakinan akan nilai dasar itulah yang menjadikan bangsa Jepang memiliki sosok kemandirian, kepribadian yang kuat, pekerja keras, disiplin dan tak kenal menyerah, sehingga bangsa Jepang mampu mengatasi masalah dengan cepat seperti dalam Restorasi Meiji (1868). Restorasi Meiji (明治維新 Meiji-ishin), dikenal juga dengan sebutan Revolusi Meiji atau Pembaruan Meiji, adalah serangkaian kejadian yang berpuncak pada pengembalian kekuasaan di Jepang kepada Kaisar pada tahun 1868. Restorasi Meiji ini menyebabkan perubahan besar-besaran pada struktur politik dan sosial Jepang, dan berlanjut hingga zaman Edo, sering juga disebut akhir Keshogunan Tokugawa dan awal zaman Meiji :https://id.wikipedia.org/wiki/Restorasi_M eiji. Peristiwa lain yaitu saat Jepang menghadapi Perang Dunia ke 2 (1945), Amerika Serikat menjatuhkan bom atom di kotaHiroshima dan Nagasaki Jepang pada bulan Agustus 1945 dengan persetujuan dari Britania Raya sebagaimana tertuang dalam Perjanjian Quebec. Dua operasi pengeboman yang menewaskan sedikitnya 129.000 jiwa ini merupakan penggunaan senjata nuklir. Amerika Serikat sebelumnya melaksanakan kampanye pengeboman yang meluluhlantakkan banyak kota di Jepang. Bersama Britania Raya dan Cina, Amerika Serikat meminta pasukan Jepang menyerah dalam Deklarasi Potsdam tanggal 26 Juli 1945 atau menghadapi "kehancuran cepat dan besar". Jepang mengabaikan ultimatum tersebut dan Jepang menolak memenuhi tuntutan Sekutu untuk menyerah tanpa syarat.

Tragedi lain yang dialami bangsa Jepang yaitu peristiwa Gempa Bumi yang disertai tsunami Tōhoku 2011suatu Gempa Bumi lepas pantai Samudra Pasifik yang berkekuatan 9,0 dan mengakibatkan gelombang tsunami setinggi 10 meter $(33 \mathrm{ft})$, berada di lepas pantai Semenanjung Oshika pantai timur Tōhoku pada 11 Maret 2011, pukul 05:46 UTC (14:46 waktu 
setempat) pada kedalaman 24,4 kilometer (15,2 mil). Laporan Japanese National Police Agency (JNPA) menyatakan bahwa 15.269 tewas dan 8.526 lainnya hilang di enam prefektur, dikawatirkan jumlah korban tewas jauh lebih tinggi. Kekuatan 9,0 menjadikan gempa ini sebagai gempa terbesar yang mengguncang Jepang sepanjang sejarah dan satu dari empat gempa terbesar di dunia sejak pencatatan gempa modern dimulai. Gempa ini dianggap sebagai yang terbesar yang mengguncang Jepang dalam 1.200 tahun terakhir

:https://id.wikipedia.org/wiki/Gempa_bumi _dan_tsunami_T\%C5\%8Dhoku_2011.

Fakta sejarah membuktikan, bangsa Jepang dalam waktu cepat dapat mengatasi dampak tragedy tersebut. Sekarang Jepang bangkit sebagai negara maju di berbagai bidang. Jepang dapat digambarkan sebagai suatu bangsa telah menempatkan nilai dasar kehidupan sebagai pondasi dan kerangka eksistensi yang kokoh.

Nilai dasar kehidupan bangsa Jepang yang dijadikan pondasi dan kerangka eksistensi, dapat terungkap dalam Bushido. Secara etimologis Bushi" berarti ksatria dan "Do" artinya jalan. Bushido dapat diartikan sebagai jalan kehormatan yang harus ditempuh oleh orang Jepang untuk menyempurnakan hidup. Bushido (武士道?), secara harfiah “jalan prajurit”, adalah kata dalam bahasa Jepang untuk cara hidup samurai, cara hidup dengan konsep ksatria. Etimologisnya dari kata bushido Jepang, yang berasal dari Dinasti Zhou (1111-256 SM) (Zhang, dan Fan, 2003) atau (1.818-221 SM) (de Bary, dan Bloom) Zhou Cina bi 周髀 (Cullen, 1996) dan kata wushidao (武士道), berarti seorang prajurit terlatih dalam seni bela diri. Singkatan "wushi," (武士) dibagi menjadi dua bagian, pertama istilah "wu" ( 武 ) menggambarkan orang yang kompeten dalam seni bela diri seperti Raja Wu, dengan jabatan kedua “shi," (士) tentara. Kedua karakter bersama-sama (武 士) berarti prajurit atau penjaga istana. Bagian terakhir dari kata, “dao" (道) adalah sama dengan "melakukan" dalam bahasa Jepang, yang berarti "cara" (Dao, 2003) seperti seni bela diri Kendo Jepang ( 剣 道) sehingga diartikan “jalan pedang”. Bushido (Kanji: 武士道 “tatacara ksatria") juga diartikan adalah sebuah kode etik kepahlawanan golongan Samurai dalam feodalisme Jepang. Samurai sendiri adalah sebuah strata sosial penting dalam tatanan masyarakat feodalisme Jepang. Secara resmi, Bushido dikumandangkan dalam bentuk etika sejak zaman Shogun Tokugawa. Makna bushido itu sendiri adalah sikap rela mati negara/kerajaan dan kaisar. Biasanya para samurai dan Shogun rela mempartaruhkan nyawa demi tujuan itu, jika ia gagal, ia akan melakukan seppuku (harakiri): https://indoculture.wordpress.com/2013/07 /18/semangat-bushido/. Bushido dalam manifestasinya sebagai identitas jati diri bangsa Jepang melalui delapan kebajikan Bushido, yaitu :

\section{(1) Gi ( integritas)}

Integritas mengandung arti keutuhan meliputi seluruh aspek kehidupan, terutama antara pikiran, perkataan, dan perbuatan. Nilai ini sangat dijunjung tinggi dalam falsafah bushido dan merupakan dasar untuk mengerti tentang moral dan etika serta menjalankannya secara utuh dan menyeluruh. Integritas berarti kesempurnaan, kesatuan, keterpaduan atau ketulusan, sangat tepat untuk mendukung pembentukan sosok pribadi manusia sesuai yang diharapkan yaitu manusia "paripurna" atau secara sederhana ialah manusia yang penuh dengan "kemuliaan". Integritas seringkali ditujukan pada orang yang dianggap sudah baik secara mental maupun spiritual. Karena itu kata integritas melekat pada pribadi orang-orang yang "arif dan bijaksana" yang dalam kehidupan kesehariannya mampu menjadi sosok 
Kiryoku, Volume 3 No 32019

e-ISSN: 2581-0960 p-ISSN: 2599-0497

Tersedia online di http://ejournal.undip.ac.id/index.php/kiryoku

manusia panutan dan sebagai teladan. Bagi seoarang pemimpin, integritas merupakan hal yang utama. Karena integritas adalah kualitas paling vital yang harus dimiliki oleh seorang pemimpin (Damar Priyambodo:

http://goosejarah.blogspot.co.id/2012/10/fil safat-bushido.html ).

\section{(2). Yu (keberanian)}

Keberanian merupakan asset yang berharga bagi siapapun yang hidup di dunia ini. Tanpa keberanian seseorang tidak akan menjadi siapa-siapa dan tidak akan meraih kesuksesan. Keberanian bisa menjadikan sesuatu yang dianggap mustahil menjadi kenyataan. Keberanian memungkinkan seseorang untuk keluar dari kesulitan dan bahkan berhasil meraih kesuksesan. Seseorang yang batinnya memang pemberani akan menunjukan loyalitas dan kasih sayang pada pimpinan dan orangtua. Mereka juga mempunyai kesabaran, sikap toleran, serta menghargai apa saja. Bukan dikatakan pemberani karena seseorang cepat meluapkan amarahnya. Seseorang pemberani adalah mereka yang dapat menguasai diri atau nafsunya sewaktu marah (Damar Priyambodo:

http://goosejarah.blogspot.co.id/2012/10/fil safat-bushido.html).

\section{(3). Jin ( Murah Hati)}

Mencintai sesama, kasih sayang dan simpati. Bushido memiliki aspek keseimbangan antara maskulin (yin) dan feminine (yang). Jin mewakili sifat feminine. Meski berlatih ilmu pedang dan strategi perang, para samurai harus memiliki sifat pengasih dan peduli pada sesama manusia. Sikap ini harus tetap ditunjukkan baik di siang hari yang terang benderang, maupun di kegelapan malam. Kemurahan hati juga ditunjukkan dalam hal memaafkan. Mencintai sesama, kasih saying dan simpati. (Damar Priyambodo: http://goosejarah.blogspot.co.id/2012/10/fil safat-bushido.html )

(4). Rei (Hormat dan Santun kepada orang lain)

Bersikap santun dan hormat pada orang lain. Ksatria tidak pernah bersikap kasar dan ceroboh, namun senantiasa menggunakan kode etiknya secara sempurna sepanjang waktu. Sikap santun dan hormat tidak saja ditujukan pada pimpinan dan orang tua, namun kepada tamu atau siapa pun yang ditemui. Sikap santun meliputi cara duduk, berbicara, bahkan dalam memperlakukan benda ataupun senjata. Hingga saat ini kesantunan para samurai masih terlihat pada cara orang jepang menundukkan kepalanya sebagai tanda hormat (Damar Priyambodo,

http://goosejarah.blogspot.co.id/2012/10/fil safat-bushido.html).

(5). Makoto-Shin (Kejujuran dan tulus ikhlas)

Samurai mengatakan apa yang mereka maksudkan, dan melakukan apa yang mereka katakan. Mereka membuat janji dan berani menepatinya. Jujur dan tulus ikhlas merupakan kode etik samurai yang berarti berkata atau memberikan suatu informasi yang sesuai kenyataan dan kebenaran. Para ksatria harus menjaga ucapannya dan selalu waspada tidak menggunjing, bahkan saat melihat atau mendengar hal-hal buruk tentang siapapun. (Damar Priyambodo, http://goosejarah.blogspot.co.id/2012/10/fil safat-bushido.html).

(6). Meiyo (menjaga nama baik dan kehormatan)

Samurai akan menghormati etika, bukan talenta. Dan mereka menghormati perbuatan, bukan pengetahuan. Salah satu cara mereka menjaga kehormatan adalah tidak menyia-nyiakan waktu dan menghindari perilaku yang tidak berguna. Jika anda di depan publik, meski tidak 
bertugas, kau tidak boleh sembarangan bersantai. Lebih baik kau membaca, berlatih kaligrafi, mengkaji sejarah, atau tata krama keprajuritan (Damar Priyambodo, http://goosejarah.blogspot.co.id/2012/10/fil safat-bushido.html).

\section{(7). Chugo (kesetiaan pada pemimpin)}

Kesetiaan ditunjukkan dengan dedikasi yang tinggi dalam melaksanakan tugas. Kesetiaan seorang ksatria tidak saja saat pimpinannya dalam keadaan sukses dan berkembang. Bahkan dalam keadaan sesuatu yang tidak diharapkan terjadi, pimpinan mengalami banyak beban permasalahan, seorang ksatria tetap setia pada pimpinannya dan tidak meninggalkannya. Puncak kehormatan seorang samurai adalah mati dalam menjalankan tugas dan perjuangan. Seperti sabda Rasulullah "engkau tetap harus setia mendengar dan taat kepada pemimpin meskipun ia memukul punggungmu atau mengambil hartamu, maka tetaplah untuk setia mendengar dan taat". (Damar Priyambodo).

\section{(8). Tei ( peduli)}

Tak peduli seberapa banyak kau menanamkan loyalitas dan kewajiban keluarga di dalam hati, tanpa perilaku baik untuk mengekspresikan rasa hormat dan peduli pada pimpinan da orang tua, maka kau tidak bisa dikatakan sudah menghargai cara hidup samurai (Damar Priyambodo)

\subsubsection{Kerangka epistemologis}

\section{Bagaimana}

cara

mengaktualisasikan nilai dasar kehidupan yang sedemikian mendasar menjiwai dan memberi watak cara berfikir dan cara bertindak bangsa Jepang mengenai arti hidup dan kehidupan bermasyarakat, berbangsa dan bernegara. Cara bangsa Jepang dalam mengaktualisasikan nilai dasar kehidupan Bushido dapat terlihat bagaimana bangsa Jepang dapat mengejar ketinggalan mereka dari bangsa Barat, karena mereka memiliki keinginan belajar dan dapat memanfaatkan suatu momentum untuk kepentingan mereka (negara). Misalnya dalam peristiwaperistiwa seperti Restorasi Meiji (1868), bencana gempa bumi dahsyat Kanto (1923) serta pengeboman Hiroshima dan Nagasaki (1945), Peristiwa gempa dan tsunami (2012) dapat dimanfaatkan sebagai suatu hal positif dan dijadikan suatu pelajaran dan momentum untuk menjadi lebih baik ( https://id.wikipedia.org/wiki/Restorasi_M eiji). Jadi, rasa keinginan belajar dan dapat memanfaatkan suatu momentum untuk kepentingan negara adalah salah satu sikap dan perilku moral Bushido orang Jepang. Melalui Restorasi Meiji angkatan perang Jepang dibangun secara modern, angkatan darat menerapkan strategi Jerman dan angkatan laut menerapkan strategi Inggris. Kementerian Pertahanan tidak bertanggung jawab kepada Parlemen tetapi kepada Tenno (Kaisar). Hal ini menjadikan kedudukan Kementerian Pertahanan sangat kuat dan menjadi menjadi Gunbatsu (pemerintahan diktator militer). Bersamaan dengan modernisasi angkatan perang muncul kembali semangat Bushido sebagai dasar jiwa ketentaraan yang melandasi pendidikan militer di Jepang ( https://indoculture.wordpress.com/2013/0 7/18/semangat-bushido/Ahmad Elqorni).

\subsubsection{Kerangka Aksiologis}

Norma apa yang menjadi pengangan dan arah dalam mencapai tujuan atau mengaktualisasikan nilai dasar kehidupan yang sedemikian mendasar menjiwai dan memberi watak cara berfikir dan cara bertindak bangsa Jepang mengenai arti hidup dan kehidupan bermasyarakat, dan bernegara. Persoalan norma dalam aksiologi hingga saat ini masih terdapat perdebatan, misalnya mengenai pengeboman Hiroshima dan Nagasaki terkait dengan kontroversi etika, legal dan militer atomic bombings of Hiroshima and Nagasaki yang dilakukan oleh Amerika Serikat pada tanggal 6 Agustus dan 9 Agustus 1945 demi mengakhiri Perang Dunia Kedua (1939-1945). Di satu sisi 
dianggap sudah tepat karena terbukti membuat Jepang menyerah, namun di sisi yang lain dianggap tidak tepat karena apapun tujuan baiknya telah mengakibatkan korban sipil yang banyak berjatuhan:

https://id.wikipedia.org/wiki/Debat_menge nai_pengeboman_Hiroshima_dan_Nagasa

ki.

Bushido dalam manifestasinya sebagai identitas jati diri bangsa Jepang melalui delapan kebajikan Bushido yang mengandung nilai moral, yaitu :

\section{(1) Gi (integritas)}

Integritas mengandung arti keutuhan seluruh aspek kehidupan, terutama antara pikiran, perkataan, dan perbuatan. Integritas berarti, kesatuan, keterpaduan atau ketulusan, sangat baik untuk mendukung pembentukan sosok pribadi manusia sesuai yang diharapkan Karena itu kata integritas melekat pada pribadi orangorang yang "arif dan bijaksana" yang dalam kehidupan kesehariannya mampu menjadi sosok manusia panutan dan sebagai teladan. Karena integritas adalah kualitas paling vital yang harus dimiliki oleh seorang pemimpin. (Damar Priyambodo:

http://goosejarah.blogspot.co.id/2012/10/fil safat-bushido.html )

\section{(2). $\mathrm{Yu}($ keberanian)}

Keberanian merupakan asset yang berharga bagi siapapun yang hidup di dunia ini. Tanpa keberanian seseorang tidak akan menjadi siapa-siapa dan tidak akan meraih kesuksesan. Keberanian bisa menjadikan sesuatu yang dianggap mustahil menjadi kenyataan. Keberanian memungkinkan seseorang untuk keluar dari kesulitan dan bahkan berhasil meraih kesuksesan. Seseorang yang batinnya memang pemberani akan menunjukan loyalitas dan kasih sayang pada pimpinan dan orangtua. Mereka juga mempunyai kesabaran, sikap toleran, serta menghargai apa saja. Seseorang pemberani adalah mereka yang dapat menguasai diri atau nafsunya sewaktu marah (Damar Priyambodo:

http:/goosejarah.blogspot.co.id/2012/10/fil safat-bushido.html).

\section{(3). Jin ( Murah Hati)}

Mencintai sesama, kasih sayang dan simpati. Bushido memiliki aspek keseimbangan antara maskulin (yin) dan feminine (yang). Jin mewakili sifat feminine. Meski berlatih ilmu pedang dan strategi perang, para samurai harus memiliki sifat pengasih dan peduli pada sesama manusia. Kemurahan hati juga ditunjukkan dalam hal memaafkan. Mencintai sesama, kasih sayang dan simpati. Meski berlatih ilmu pedang dan strategi perang, para samurai harus memiliki sifat pengasih dan peduli pada sesama manusia (Damar Priyambodo, http://goosejarah.blogspot.co.id/2012/10/fil safat-bushido.html).

(4). Rei (Hormat dan Santun kepada orang lain)

Ksatria tidak pernah bersikap kasar dan ceroboh, namun senantiasa menggunakan kode etiknya secara sempurna sepanjang waktu. Sikap santun dan hormat tidak saja ditujukan pada pimpinan dan orang tua, namun kepada tamu atau siapa pun yang ditemui. Sikap santun meliputi cara duduk, berbicara, bahkan dalam memperlakukan benda ataupun senjata. (Damar Priyambodo, http://goosejarah.blogspot.co.id/2012/10/fil safat-bushido.html)

(5). Makoto - Shin (Kejujuran dan tulus ikhlas)

Samurai mengatakan apa yang mereka maksudkan, dan melakukan apa yang mereka katakan. Mereka membuat janji dan berani menepatinya. Jujur dan tulus ikhlas merupakan kode etik samurai yang berarti berkata atau memberikan suatu 
Kiryoku, Volume 3 No 32019

e-ISSN: 2581-0960 p-ISSN: 2599-0497

Tersedia online di http://ejournal.undip.ac.id/index.php/kiryoku

informasi yang sesuai kenyataan dan kebenaran (Damar Priyambodo, http://goosejarah.blogspot.co.id/2012/10/fil safat-bushido.html).

(6). Meiyo ( menjaga nama baik dan kehormatan)

Samurai akan menghormati etika, bukan talenta, mereka menghormati perbuatan, bukan pengetahuan. Salah satu cara menjaga kehormatan adalah tidak menyianyiakan waktu dan menghindari perilaku yang tidak berguna (Damar Priyambodo, http:/goosejarah.blogspot.co.id/2012/10/fil safat-bushido.html).

(7). Chugo (kesetiaan pada pemimpin)

Kesetiaan ditunjukkan dengan dedikasi yang tinggi dalam melaksanakan tugas. Kesetiaan seorang ksatria tidak saja saat pimpinannya dalam keadaan sukses dan berkembang. Bahkan dalam keadaan sesuatu yang tidak diharapkan terjadi, pimpinan mengalami banyak beban permasalahan, seorang ksatria tetap setia pada pimpinannya dan tidak meninggalkannya (Damar Priyambodo, http://goosejarah.blogspot.co.id/2012/10/fil safat-bushido.html)

(8). Tei ( peduli)

Menanamkan loyalitas dan kewajiban kepada sesama di dalam hati, disertai perilaku baik untuk mengekspresikan rasa hormat dan peduli pada orang lain, maka kita bisa dikatakan sudah menghargai cara hidup samurai (Damar Priyambodo. http://goosejarah.blogspot.co.id/2012/10/fil safat-bushido.html). Itulah butir-butir nilai moral Bushido yang ditemukan dalam penelitian ini.

\section{SIMPULAN}

a. Untuk memahami secara mendalam dan utuh tentang profil identitas jati diri bangsa Jepang perlu menelusuri proses kehidupan bangsa Jepang yang telah dilalui dan nilai-nilai tradisi yang ada dalam masyarakat Jepang yang tidak terkikis oleh derasnya arus modernisasi.Kemudian juga peristiwa-peristiwa seperti Restorasi Meiji (1868),

b. Secara filosofis nilai moral dalam Bushido sudah mengakar, mewarni cara hidup dan memberi arah kehidupan masyarakat bangsa Jepang.

c. Perkembangan dan penguatan jati diri bangsa Jepang sejalan dengan proses jaman yang dilalui serta peristiwa sejarah yang dialami.

\section{DAFTAR REFERENSI}

Widisuseno, Iriyanto. (2015). Etika Taoisme dan Masyarakat Madani, UNDIP. Press, Semarang.

Widisuseno, Iriyanto. (2018). Mengenal Profil Karakter Bangsa Jepang Melalui Filsafat Ganbaru, Kiryoku,

Widisuseno, Iriyanto. (2007). Pendidikan Pancasila, BP. Undip Press, Semarang

https://www.researchgate.net/publication/2 79275033 Bushido dalam Masyara kat_Jepan_Modern ( Bambang Wibawarta).

http://manfaat94.blogspot.co.id/2016/07/un sur-unsur-danprosespembentukan.html 